DOI 10.18551/rjoas.2021-04.14

\title{
TYPES OF SOAK SOLUTIONS AND DRYING TIME TO EUCHEUMA COTTONII'S SEMI REFINED CARRAGEENAN CHARACTERISTICS
}

\author{
Purnomo, Candra*, Suhanda Juhana, Asmawati \\ Study Program of Fisheries Product Technology, Faculty of Fisheries and Marine Affairs, \\ University of Lambung Mangkurat, Banjarbaru, Indonesia \\ *E-mail: candra1077@ulm.ac.id
}

\begin{abstract}
Seaweed has a high potential value after being processed into semi-pure carrageenan flour (Semi Refined Carrageenan, SRC) and pure carrageenan (Refined carageenan, RC). Carrageenan is a yellowish white flour from seaweed type Eucheuma cottonii, which can form a gel so that it plays a very important role in the food and medicine industry, including as a stabilizer, thickener and emulsifier. This research examines the comparision of the effectiveness of three solutions, namely soaking with rice washing water, well water, and $\mathrm{CaCO}_{3} 2 \%$ solution in the initial immersion stage. The next stage examines the effect of different drying times using manual drying methods by exposing the carrageenan extract to the sun for 6 and 8 hours. The test results of sulfate level, moisture level, ash level, appearance, odor, texture, and color showed that the soaking treatment with rice washing water and drying for 6 hours $\left(\mathrm{A}_{2} \mathrm{~B}_{1}\right)$ with data were $403.4 \mathrm{mg} / \mathrm{Kg}$ (sulfate level); $6.42 \%$ (water levelt); 24.42\% (ash level); 8,4 (appearance); 6.9 (odor); 8.5 (texture); and 8.1 (color). Further research can be focused on the closed SRC drying process to avoid environmental contamination and the effect of storage under vacuum and non-vacuum conditions on the chemical, physical, and organoleptic characteristics of SRC flour.
\end{abstract}

\section{KEY WORDS}

Noodles, Eucheuma cottonii, SRC, Monopterus albus zuieuw.

The diversity of seaweed in Indonesia is the largest compared to other countries. Seaweed consists of 4 classes, namely green algae (Cholophyceae), brown algae (Phaeophyciae), blue algae (Cyanophyceae) and red algae (Rhodophyceae). Eucheuma cottonii red algae can produce carrageenan (Suparmi and Sahri, 2009).

One type of seaweed is Algae Sargassum sp. or brown algae. This algae is a genus of Sargassum which belongs to the class Phaeophyceae, Sargassum sp. contains $\mathrm{Mg}, \mathrm{Na}, \mathrm{Fe}$, tannin, iodine, and phenol which have the potential as an antimicrobial agent against several types of pathogenic bacteria that can cause diarrhea (Sastry and Rao, 1994). Sargassum sp. contains alginate and iodine which are useful for the food, pharmaceutical, cosmetic and textile industries (Kadi, 2008). Seaweed has a high potential value after being processed into semi-pure carrageenan flour (Semi Refined Carrageenan, SRC) and pure carrageenan (Refined carageenan, $\mathrm{RC}$ ).

Carrageenan is yellowish white flour from seaweed type Eucheuma cottonii, which can form a gel so that it plays a very important role in the food and medicine industry, including as a stabilizer, thickener and emulsifier (Dewi, et al, 2012).

In the process of extracting seaweed into carrageenan, there is a stage of soaking dry seaweed which aims to remove salts and odors. The fishy smell is due to the amine content in seaweed. The odor of amines (ammonia (NH3)) needs to be removed by pre-treatment, namely by adding ingredients to the solution when soaking dry seaweed (Xiren and Aminah, 2014).

Research on carrageenan processing has been carried out, including the characterization of SRC Eucheuma cottonii from different regions (Sormin et al., 2018), with a soaking process using $2 \% \mathrm{CaCO} 3$ solution. Another study conducted by Rosalita et al. (2018) regarding the type of soaking solution on the quality of the seaweed pudding. This 
study used rice washing water and lime solution which aims to reduce the smell of mixing amines with seaweed.

The carrageenan processing stage also includes a drying process to obtain dry carrageenan and then mash it into powder / flour. The drying process is done manually or mechanically. Manual drying by drying the carrageenan extract in the sun until the carrageenan is dry. In mechanical drying using drying equipment such as ovens, drying drums and spray drying.

The availability of mechanical dryers in the community is very limited, apart from the relatively expensive prices and not all regions sell these tools. So that drying with the manual method, it is very easy to implement in the community. Only by preparing plastic or bamboo / wood trays and then drying them in the sun, the drying process of carrageenan extract can be easily carried out.

Based on this description, research is needed to examine the effectiveness of the dry seaweed immersion process and the carrageenan extract drying process (SRC). This research examines comparing the effectiveness of three solutions, namely soaking with rice washing water, well water, and $2 \% \mathrm{CaCo} 3$ solution in the initial immersion stage. The next stage examines the effect of different drying times using manual drying methods by exposing the carrageenan extract to the sun for 6 and 8 hours.

\section{METHODS OF RESEARCH}

The research was conducted for four months from August to November 2020 at the Laboratory of Raw Materials and Organoleptic for Processing Fisheries Products and the Laboratory of Animal Husbandry Faculty of ULM Agriculture.

The equipment used in this study were basin, measuring cup, knife, $\mathrm{pH}$ paper, parapara, blender, flour filter, analytical scale, and analysis equipment. The materials used are seaweed (Eucheuma cottonii), water, $\mathrm{CaCO} 3$, rice, plastic bags, code paper, and materials for analysis.

The dried seaweed is washed, then soaked according to the treatment, namely with well water, rice washing water and $2 \% \mathrm{CaCO} 3$ solution until all the seaweed is soaked, the seaweed is soaked for 10 hours to remove salts and odors. After the first soaking, the seaweed is rinsed 1 time then extracted, which is soaked for 24 hours in a $0.5 \% \mathrm{KOH}$ solution with a ratio of dry seaweed and a solution of 1:10 (w/v). Seaweed is washed with clean water to a neutral $\mathrm{pH}$ (about 7), the washing product is called SRC. The SRC which was still wet was drained, cut into pieces about $1-2 \mathrm{~cm}$ in length and dried under full sun for 6 hours and 8 hours of drying. After drying, the SRC is refined into flour by blending it for all treatments. Then the SRC was analyzed for organoleptic, moisture content, ash content, and sulfate content.

The design used in this research was factorial completely randomized design (CRD) with immersion solution factor $(A)$ and drying time $(B)$. Each factor consists of 3 and 2 levels and 3 (three) repetitions with the following details:

- $\mathrm{A} 0=$ ordinary water;

- $\mathrm{A} 1=2 \% \mathrm{CaCO} 3$ solution;

- $\quad \mathrm{A} 2$ = rice washing water;

- $\mathrm{B} 1=6$ hours drying time;

- $\mathrm{B} 2=8$ hours drying time.

\section{RESULTS AND DISCUSSION}

Carrageenan semi refine processing with solution type treatment and drying time resulted in different levels of sulfate (SO4) ( $p>0.05$ ). The highest sulfate level was in the $\mathrm{CaCO} 3$ solution treatment and the drying time was 6 hours (A1B1) (Figure 1).

SRC sulfate levels in each treatment were still in accordance with the SNI carrageenan (15000 - $40000 \mathrm{mg} / \mathrm{Kg}$ (DPBM, 2018)), which is in the range of $403.4-738.34 \mathrm{mg} / \mathrm{kg}$. The 
soaking process in each solution for 10 hours can reduce the strength of the sulfate group bonds in seaweed.

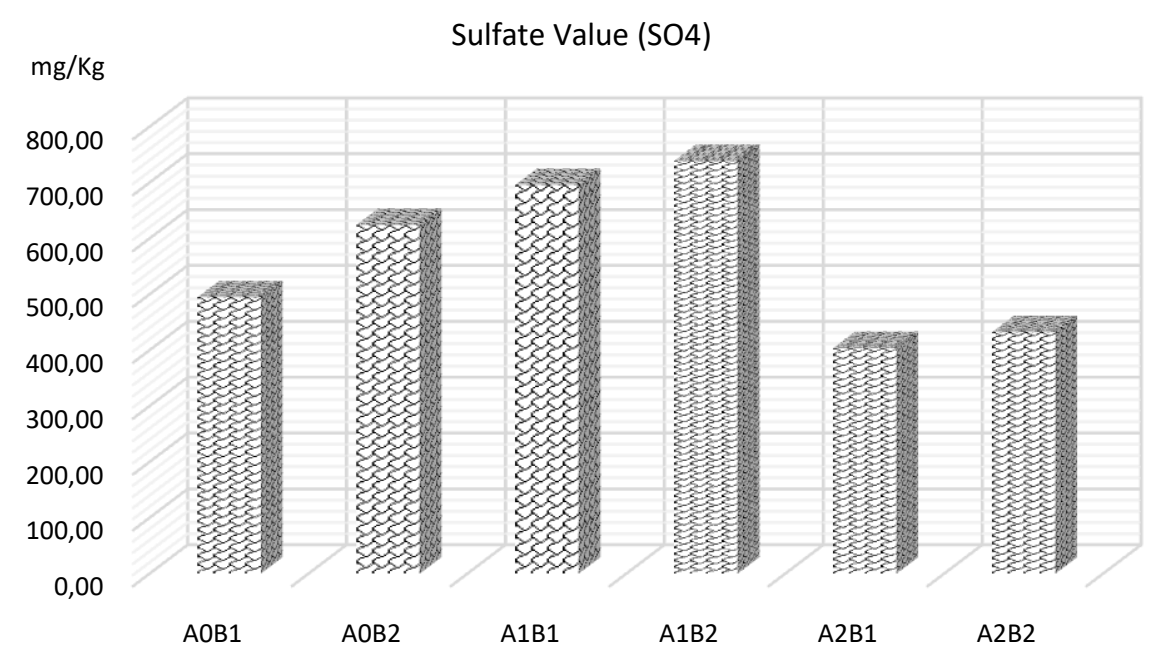

Figure 1 - Diagram of the SRC sulfate (SO4) scores

The sulfate level in the soaking treatment using rice washing water (A2B1 and A2B2) was the lowest compared to other treatments ( $p>0.05$ ). This is influenced by the rice washing solution when soaking causes an acidic atmosphere in the seaweed so that during the immersion process, the sulfate groups in the carrageenan bonds are weaker than the other solutions (controls (A0B1 and A0B2) and $\mathrm{CaCO} 3$ (A1B1 and A1B2)).

Puspitasari (2008) explains that water washing rice when soaking produces acid and reduces the $\mathrm{pH}$ to 4.5 . Basmal et al (2003) stated that the $\mathrm{KOH}$ solution given during the extraction process was able to react with the sulfate group in carrageenan $(\mathrm{K})$ to form $\mathrm{K} 2 \mathrm{SO} 4$ salts and sulphuric acid, the sulfate levels decreased with increasing concentration of $\mathrm{KOH}$ solution given during the extraction process.

The drying process in each treatment showed that the longer the drying time, the smaller the sulfate content in the SRC. This condition is the same as it is suspected that the water evaporation process that occurs can increase the level of sulfate because the calculation is based on the total weight of the SRC.

The soaking solution treatment and drying time gave different water level $(p>0.05)$ with the lowest water level in the A2B2 treatment (rice washing solution and 8 hours drying time) (Figure 2). The process of soaking the grass with the formation of acidic conditions by washing rice water results in the release of water which is chemically bound so that it is easier to evaporate when drying. Figures and Suhartono (2000) explained that the glyosidic bonds of carrageenan to water molecules can weaken as the $\mathrm{pH}$ decreases, because $\mathrm{H}+$ ions help the hydrolysis of the glyosidic bonds in the carrageenan molecules.

The water level in each treatment is directly proportional to the conditions of the SRC sulfate level. This event is related to the ability of the sulfate groups on the SRC to be able to bind water so that in each immersion treatment the moisture and sulfate level conditions are the same. Research by Romenda et al (2013) reported that the smaller the sulfate level in carrageenan, the less water-binding ability. Imeson (2003) adds that the sulfate level produces repulsive forces between the negatively charged sulfate groups along the polymer chain causing the polymer chain to become stiff and tightly pulled. The hydrophilic nature causes the molecule to be surrounded by immobile water.

In Figure 3, the SRC ash level data is shown with the treatment of the type of immersion solution and the drying time. The SRC ash level data in each treatment ranged from $24.33-25.00 \%(p<0.05)$ and was below the SNI standard, namely $15-40 \%$ (DPBM, 2018). 
The SRC ash level in this study is still in the range of SNI, but is still in the high category. This condition is thought to be caused by the drying process with open drying so that dust particles can still stick to the SRC.

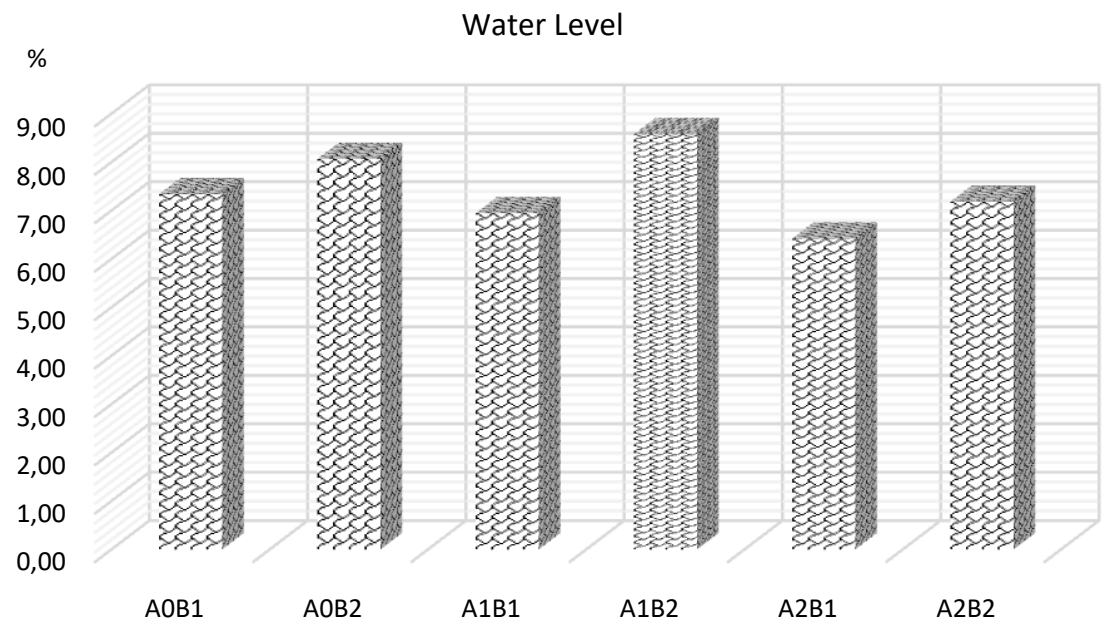

Figure 2 - SRC water level diagram

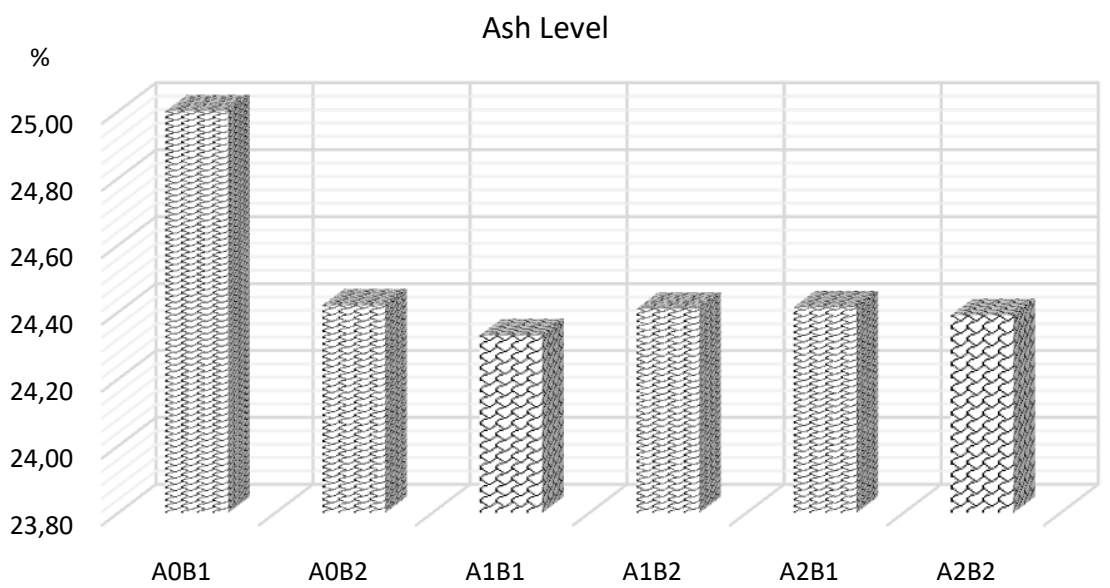

Figure 3 - The SRC ash level diagram

Romenda, et al. (2013) suggested that these results have an effect on gel strength in carrageenan. The greater the ash content produced, the greater the sulfate content obtained, this is because during the ashing process some sulfates will evaporate into SO2 and others will become minerals or oxides that do not evaporate during ashing.

In Figure 4, a graph of the data on the organoleptic value of the appearance, smell, texture and color of the SRC is presented. Soaking solution treatment and drying time had a significant effect on each of the SRC organoleptic value specifications $(p>0.05)$.

The SRC visibility value is in the range of 5 to 8.4. The highest appearance value in the A2B1 treatment is 8.4 (clean, normal color), indicating that the effect of rice washing water can release dirt (sand, stones, etc.) on the seaweed when soaking it so that it is easily released during cleaning.

Drying for 8 hours can reduce the appearance value of each treatment $(p>0.05)$. The drying process by drying can cause the white colour of the SRC to fade to a bit darker. Arfini (2013) states that the non-enzymatic browning process occurs due to the drying process so that the bright color of carrageenan is faded.

The SRC organoleptic odor showed significantly different values in each treatment, and the highest value in the control treatment was 7.4 (neutral odor). The specification of this value is also found in the A2B1 treatment ( $p<0.05$ for control). 
Alum and chlorine in the control solution (tap water) can eliminate the fishy odor in seaweed. Mariyana et al (2015) reported that ammonia will react with chlorine or hypochloric acid and form monochloramine, dichloramine or ticrolamine depending on the ratio of the concentration of reagents and temperature. $\mathrm{NH} 3$ can be removed as a gas through aeration or reaction with chlorine. Until it becomes harmless chloramine or it becomes N2.

Rice washing water in the A2B1 treatment can also reduce the fishy smell of seaweed. Rosalita et al (2018) report that rice washing water produces acetic acid so that it can minimize the smell of ammonia (NH3) in seaweed.

SRC Organoleptic value

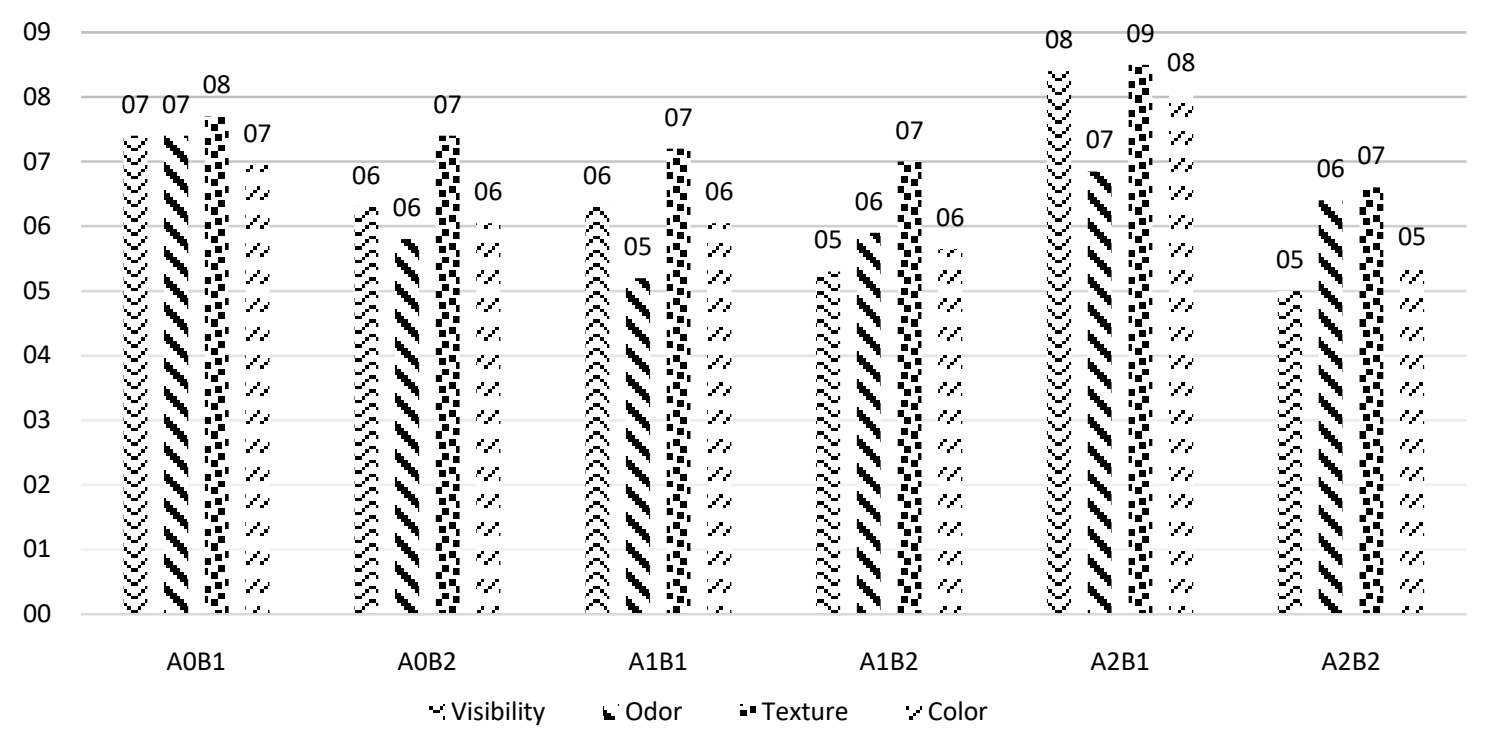

Figure 4 - Graph of the organoleptic value of the appearance, smell, texture and color of the SRC

Figure 4 shows the SRC texture value in the range of $6.6-8.5(p>0.05)$. The highest texture value in A2B1 treatment (not clotting) was in line with the low sulfate value in this treatment $(403.4 \mathrm{mg} / \mathrm{Kg}$ ). Campo et al (2009) stated that the high strength value of pure carrageenan kappa gel was caused by the low value of carrageenan sulfate levels. Reduction of the sulfate groups can cause cross-linking resulting in the formation of a gel phase.

The SRC color in the treatment showed a range of values, namely $5.4-8.1(p>0.05)$ (Figure 4). The highest color value in treatment A2B1 (White), the color organoleptic phenomenon is in line with appearance specifications with a positive correlation.

\section{CONCLUSION}

Based on the results of chemical tests (sulfate content, moisture content and ash content) and organoleptic tests (appearance, smell, texture and color), the best treatment was A2B1 (rice washing solution and 8 hours drying time). Further research can be focused on the closed SRC drying process to avoid environmental contamination and the effect of storage under vacuum and non-vacuum conditions on the chemical, physical and organoleptic characteristics of SRC flour.

\section{ACKNOWLEDGMENTS}

The gratitude are conveyed to LPPM ULM for funding research through PNBP PDUPT with Rector Decree number 701 / UN8 / PP / 2020 and Contract Number 023.17.2.6777518 / 2020. 


\section{REFERENCES}

1. Angka SL, Suhartono TS. 2000. Bioteknologi Hasil Laut. Bogor: Pusat Kajian Sumber Daya Pesisir and Lautan. Institut Pertanian Bogor.

2. Arfini F. 2013. Optimasi Proses Pembuatan Karaginan Dari Rumput Laut Merah (Euchema cottonii). Jurnal Galung Tropika. 1(1): 23 - 32.

3. Basmal J, Syarifudin, Ma'ruf FW. 2003. Pengaruh Konsentrasi Larutan Potasium Hidroksida Terhadap Mutu Kappa-Karaginan Yang Diekstraksi Dari Eucheuma cottonii. Jurnal Penelitian Perikanan Indonesia. 9(5):95 - 103.

4. Campo VL, Kawano DF, da Silva DB, Carvalho I. 2009. Carrageenans: Biological properties, chemical modifications and structural analysis - A review. Carbohydrate Polymers. 77: 167 - 180.

5. Dewi, Cakrawati, Mustika NH. 2012. Bahan Pangan, Gizi, and Kesehatan. Bandung: Alfabeta.

6. DPBM, 2018.

7. Imeson A. 2000. Carrageenan. Dalam Phililps GO, Williams PA (eds): Handbook of Hydrocolloids. England: Wood Head Publishing.

8. Mariyana, T Joko, Nurjazuli. 2015. Efektivitas Kaporit dalam Menurunkan Kadar Amoniak and Bakteri Koliform dari Limbah Cair RSUD Tugurejo Semarang. Jurnal Kesehatan Masyarakat. 3(1): $533-539$.

9. Novianto DK, Y Dinarianasari, A. Prasetyaningrum. 2013. Pemanfaatan Membran Mikrofiltrasi Untuk Pembuatan Refined Carrageenan dari Rumput Laut Jenis Eucheuma cottonii. Jurnal Teknologi Kimia and Industri. 2(3): 109 - 114.

10. Puspitasari, D. 2008. Kajian Substitusi Tapioka dengan Rumput Laut (Eucheuma Cottoni) Pada Pembuatan Bakso. Skripsi. Jurusan Teknologi Hasil Pertanian. Fakultas Pertanian. Universitas Sebelas Maret.

11. Romenda AP., R Pramesti, AB Susanto. 2013. Pengaruh Perbedaan Jenis and Konsentrasi Larutan Alkali Terhadap Kekuatan Gel and Viskositas Karaginan Kappaphycus alvarezii, Doty. Journal Of Marine Research. 2(1): $127-133$.

12. Rosalita, H Syam, R Fadhilah. 2018. Terhadap Kualitas Organoleptik Puding Rumput Laut (Eucheuma cottonii). Jurnal Pendidikan Teknologi Pertanian. 4(1): 92 - 103.

13. Sastry and Rao. 1994. Antibacterial Substance from Marine Algae. Successive Extraction Using Benzene, Chloroform and Methanol. Department of Biochemistry, Institute of Medical Science, Banaras Hindu University. India.

14. Sormin RBD, Dwight S,Saiful, Agustina R, Stenly JF. 2018. Sifat Fisiko-Kimia Semi Refined Carrageenan dari Kota Ambon and Kabupaten Maluku Tanggara Barat. Jurnal Pengolahan Hasil Perikanan Indonesia. 21(1): 92 - 98.

15. Suparmi, A Sahri. 2009. Mengenal Potensi Rumput Laut: Kajian Pemanfaatan Sumber Daya Rumput Laut Dari Aspek Industri and Kesehatan. Jurnal Sultan Agung. 44(118): $95-116$.

16. Xiren GK., Aminah A. 2014. Elimination of seaweed odour and its effect on antioxidant activity. AIP Conference Proceedings, 399 (2014). 